Krisztina Bányai

Thoughts on the principle of ne bis in idem in the light of administrative and criminal sanctions for the legal protection of animals
Journal of Agricultural and

Environmental Law

$31 / 2021$

\title{
Krisztina BÁNYAI* \\ Thoughts on the principle of ne bis in idem in the light of administrative and criminal sanctions for the legal protection of animals**
}

\begin{abstract}
According to the well-developed interpretation of the principle of the ne bis in idem in the case law of the Court of Justice of the European Union and the European Court of Human Rights, the same conduct cannot be the subject of two proceedings or santions with similar functions and purposes. In Hungary the Constitutional Court bas interpreted the rules of the ne bis in idem in administrative and criminal procedure for animal welfare fine and sanctions for cruelty to animals in Decision 8/2017. (IV.18) AB and the legislator settled its rules in Act on administrative sanctions which came into effect from the 1st of January, 2021. The recent study through practical issues approaches how principle prevails, its problems and possible solutions in the field of unlawful conduct in animal welfare, in particular regarding the role of the prosecutor.

Keywords: the principle of the the ne bis in idem, twofold assessment, prohibiton of double proceedings, identity of facts, parallel procedure, administrative procedure, administrative fine, animal welfare fine, criminal procedure, cruelty to animals, aggregation of sanctions, the role of prosecutor in the field of animal protection.
\end{abstract}

\section{Introduction}

Animal welfare in one of the European Union's priorities, ${ }^{1}$ and the Trety of Lisbon recognizes animals as sentient beings. ${ }^{2}$ Differentiated protection of animals is justified by their sensitivity and suffering ability. ${ }^{3}$

Krisztina Bányai: Thoughts on the principle of ne bis in idem in the light of administrative and criminal sanctions for the legal protection of animals - Gondolatok a ne bis in idem elvérôl az állatok jogi védelmét szolgáló közigazgatási és büntetőjogi szankciók tükrében. Journal of Agricultural and Environmental Law ISSN 1788-6171, 2021 Vol. XVI No. 31 pp. 7-38, https://doi.org/10.21029/JAEL.2021.31.7

* Prosecutor at the Prosecutor's Office of Borsod-Abaúj-Zemplén County, PhD, e-mail: dr.banyai.krisztina@gmail.com, banyai.krisztina@mku.hu, ORCID: 0000-0003-4941-5410.

** This study has been written as part of the Ministry of Justice programme aiming to raise the standard of law education.

${ }^{1}$ Commission working document on a Community Action Plan on the Protection and Welfare of Animals 2006-2010 2006.

2 Article 13, Treaty on the Functioning of the European Union.

3 The preamble of Hungarian animal protection act emphasizes animals are living creatures that are capable of feeling, suffering and showing happiness, and it is a moral duty for every human being to respect them and guarantee their well being. Several european countries enacted this into law, most recently the british animal welfare act in May 2021, that animals with spinal cord are capable of emotion. 
Krisztina Bányai

Thoughts on the principle of ne bis in idem in the light of administrative and criminal sanctions for the legal protection of animals
Journal of Agricultural and

Environmental Law

$31 / 2021$

Act XXVIII of 1998 on the protection and sparing of animals (Animal Protection Act, hereinafter referred to as: APA) was promulgated on 1st of April 1998 and entered into force on 1st of January 1999. Besides objective liability provisions and sanctions of Act, there has emerged a subjective, guilt-based criminalization of illegal behaviors against animals; from 24th of April 2004, the legislator enacted the crime of cruelty to animals in the Criminal Code, while repealing its offense form from 3rd of September 2004, ${ }^{4}$ thus emphasizing the importance to criminalize unlawful conduct against animals. ${ }^{5}$ In criminal law, cruelty to animals often appears as a cumulative act, such as when perpetrators killed and stole magnalica pigs at a pig farm, they were judged for cruelty to animals and theft, as this was a crime against property and against environment and nature. Cruelty to animals one of the criminal offenses against environment and nature and the crime was issue of two different protected legal subjects.

Sanctions for animal welfare offenses arise in areas governed by more than one legal field, and an unlawful conduct may have legal consequences in more than one legal field, which raises the issue of double assessment. The same unlawful act may be suitable for establishing administrative proceedings for violation of the provisions of the APA and for criminal proceedings for cruelty to animals contained in Section 244 of Act C of 2012 on the Criminal Code (hereinafter referred to as: Criminal Code). The basic idea is appropriate that the independent application of two sanctions in different jurisdictions would not be a question if we take dogmatic differences of the two proceedings into account. The basis of an administrative procedure for the protection and welfare of animals contains an objective responsibility and not only a natural person can be the subject to the procedure, while criminal proceedings can be examined on a subjective, criminal basis. The administrative procedure also covers a much wider range of unlawful conduct than the criminal assessment. ${ }^{6}$

According to the current wording of cruelty to animals in the Criminal Code, any person who is engaged in the unjustified abuse or unjustified mistreatment of vertebrate animals resulting in permanent damage to the animal's health or in the animal's destruction; or who abandons, dispossess or expels a domesticated vertebrate animal or a dangerous animal is guilty of a misdemeanor punishable by imprisonment not exceeding two years. The penalty for a felony shall be imprisonment not exceeding three years, if the criminal offense is carried out in a manner to cause undue suffering to the animal, or results in permanent damage to several animals or in the destruction of more than one animal. ${ }^{7}$

${ }^{4}$ Although in Act II of 2012 on minor offences, offence procedures and the registration system of offence eliminates the parallel procedures in Section 2 (4) that says no offence can be stated if the activity or omission constitutes a crime, as well as law if government decree orders an administrative fine.

5 There are also ongoing efforts to tighten rule, for example, a referendum was initiated on 9th of December 2019 in order that cruelty to animals that caused the death of an animal to be punished by imprisonment only. The National Election Committee by 495/2019 NVB decision refused to authenticate the issue, as it concerns a prohibited subject.

68/2017. (IV.18.) AB decision [24].

${ }^{7}$ Criminal Code 244. $\$$. 
Krisztina Bányai

Thoughts on the principle of ne bis in idem in the light of administrative and criminal sanctions for the legal protection of animals
Journal of Agricultural and

Environmental Law

$31 / 2021$

However, the constitutional principle of the prohibition of double assessment and punishment has pushed the possibilities of parallel proceedings of administrative and criminal proceedings into a new direction. This study reviews the regulation of the sanction system of the two proceedings and some practical problems of application of law from the perspective of the constitutional principle of the ne bis in idem, with special regard to the role of the prosecutor.

\section{Interpretation of the ne bis in idem principle}

\subsection{In an international perspective}

The principle of the ne bis in idem, the prohibition of double jeopardy and double jeopardy, is a principle of fundamental criminal origin designed to eliminate multiple proceedings. Internationally, issues have been resolved through mutual legal assistance agreements in specific cases on the basis of legal acts, ${ }^{8}$ conventions on fundamental rights and the principle of mutual recognition, ${ }^{9}$ and in most states the rules prohibiting ne bis in idem are laid down in separate legal instruments.

Under Article 14 (7) of the International Covenant on Civil and Political Rights, ${ }^{10}$ "no one shall be liable to be tried or punished again for an offense for which he has already been finally convicted or acquitted in accordance with the law and penal procedure of each country."

Article 4 of the Protocol No. 7 to the Convention for Protection of Human Rights and Fundamental Freedoms"1 is about the right "not to be tried or punished in criminal proceedings for an offense for which one has already been acquitted or convinced, so it regulates the right of the accused in respect of a second proceeding in the same state."

Under Article 50 of the Charter of Fundamental Rights, ${ }^{12}$ applied by the courts of the European Union and the courts of the Member States, ${ }^{13}$ "no one shall be liable to be tried or punished again in criminal proceedings for an offense for which he or she has already been finally acquitted or convicted within the Union in accordance with the law."

\footnotetext{
${ }^{8}$ In Hungary, co-operation in criminal matters with other states is governed by bilateral and multilateral international treaties and, unless an international treaty provides otherwise, provided by Act XXXVIII of 1996 on International Mutual Assistance in Criminal Matters.

${ }^{9}$ For example, under Article 9 (non bis in idem) of the European Convention on Extradition of 13 December 1957 in Paris, extradition shall not be granted if final judgment has been passed by the competent authorities of the requested Party upon the person claimed in respect of the offence or offences for which extradition is requested.

10 Adopted by the United Nations General Assembly on 16 December 1966.

11 Convention by Council of Europe, signed at Rome on 4 November 1950, officially proclaimed in Hungarian: Convention for the Protection of Human Rights and Fundamental Freedoms.

${ }^{12}$ Charter of Fundamental Rights of the European Union (2012/C 326/02).

${ }^{13}$ According to the of Article 6 (1) of the Treaty on European Union: 1. The Union recognises the rights, freedoms and principles set out in the Charter of Fundamental Rights of the European Union of 7 December 2000, as adapted at Strasbourg, on 12 December 2007, which shall have the same legal value as the Treaties. It entered into force on 1 December 2009, the date of entry into force of the Treaty of Lisbon.
} 
Krisztina Bányai

Thoughts on the principle of ne bis in idem in the light of administrative and criminal sanctions for the legal protection of animals
Journal of Agricultural and

Environmental Law

$31 / 2021$

Article 54 of the Convention Implementing the Schengen Agreement ${ }^{14}$ on the application of the principle of the ne bis in idem says: "A person whose trial has been finally disposed of in one Contracting Party may not be prosecuted in another Contracting Party for the same acts provided that, if a penalty has been imposed, it has been enforced, is actually in the process of being enforced or can no longer be enforced under the laws of the sentencing Contracting Party."

The principle of the ne bis in idem has been enshrined in national laws by Constitution and in certain Acts of procedural law as a directing principle arising from the principle of legality, for limiting the criminal power of the state. The prohibition of double assessment was soon transferred to the practice of other areas of law, as unlawful conduct cannot be assessed only in criminal law. The case law of the ECtHR ${ }^{15}$ and the CJEU16 has repeatedly raised the issue of double sanctioning, administrative and criminal, on the basis of the same factual acts.

The CJEU stated in Åkerberg Fransson judgment ${ }^{17}$ regarding the cumulation of tax law and criminal law sanctions (in particular non-payment of value added tax) that the ne bis in idem principle does not preclude a Member State from imposing successively, for the same acts of non-compliance with declaration obligations in the field of valued added tax, a tax penalty and a criminal penalty in so far as the first penalty is not criminal in nature, a matter which is for the national court to determine. In this case the opinion of the Advocate General emphasized that it is practice of the Member States of the European Union to prescribe sanctions of different legal fields, especially in issues of taxation, ${ }^{18}$ environment and public security. Double sanction does not constitute an infringement of the ne bis in idem principle in itself, provided that the administrative sanction and the criminal sanction are applied with respect to each other; thus, for example, with the reduction of the penalty by the administrative sanction previously imposed. ${ }^{19}$

In case A and B v. Norway, ${ }^{20}$ the ECtHR has given a broad interpretation to the ne bis in idem principle, stating that two criminal type sanctions may be imposed under certain conditions and that proceedings should be considered as a whole if there is a close material and temporal connection between them, and the purpose and means of the procedure are complementary and the consequences of the procedure are

14 42000A0922 (02), incorporated into the primary law of the European Union by the Treaty of Amsterdam, which entered into force on 1 May 1999. Although, under Article 55 (1) any Contracting Party may declare that Article 54 is not bound for a state in the cases listed, but in accordance with Article 56, the custodial sentence already served by the convicted person, or even the non-custodial sentence, shall be taken into account in the new criminal proceedings. Article 58 of the Convention does not preclude the application of more comprehensive national provisions relating to the principle of the ne bis in idem to judgments given abroad.

${ }^{15}$ European Court of Human Rights.

${ }^{16}$ Court of Justice of the European Union.

17 Aklagaren v Hans Åkerberg Fransson C-617/10. Judgment of 26 February 2013.

18 The Member States' free choice of sanctions is justified by the need to ensure the collect of value added tax $(V A T)$ revenue, thus protecting the financial interests of the Union. See more about this: Harmati \& Kiss 2016, 63-68.

${ }^{19}$ Opinion of Advocate General P. Cruz Villalón in Case C-617/10, 94. and 96.

${ }^{20}$ Judgment of 15 November 2016, 24130/11., 29758/11. 
Krisztina Bányai

Thoughts on the principle of ne bis in idem in the light of administrative and criminal sanctions for the legal protection of animals
Journal of Agricultural and

Environmental Law

$31 / 2021$

foreseeable and proportionate to the person concerned. In Menci case, ${ }^{21}$ the CJEU entrusted to national courts the limitation of the additional burden of the accumulation of proceedings and sanctions to the extent that is strictly necessary regarding the burden of the committed infringement.

In order to establish a conflict with the prohibition of double assessment, the ECtHR applied the so-called Engel criteria ${ }^{22}$ that was developed in an earlier case and which practice the CJEU eventually adopted with the Bonda case, ${ }^{23}$ interpreting the concept of a crime and providing a broader interpretative framework for the ne bis in idem principle. The Engel criteria examine three rounds of assessment: whether an act constitutes a criminal offense under national law, the nature of the offense and the nature and gravity of the sanction applied, whether it is intended to be deterrent or preventive. For example, if two proceedings of a criminal nature have been instituted against a person, and both proceedings concern the same unlawful act (idem) and therefore two sanctions (bis) have been imposed in parallel, which are effective, proportionate and dissuasive, these are against ne bis in idem principle.

It is very important if the dual proceedings had foreseeable consequences, if they were proportionate and that the authorities made every effort to avoid double assessment. Thus, a broad interpretation of the principle of ne bis in idem was crystallized. Under the concept of the same act, historical identity must be taken into account, regardless of the legal classification and the subject protected..$^{24}$

\subsection{Ne bis in idem in Hungarian animal protection and 8/2017. (IV.18.) $\mathrm{AB}$ decision}

The Hungarian Constitutional Court (hereinafter referred to as: AB) in 38/2012. (XI.14.) $\mathrm{AB}$ decision stated that, with view of the practice of the ECtHR, judging the criminal nature of the examined conduct based on three factors. It examines whether the unlawful conduct which is the subject of the procedure constitutes a crime in the legal system of that state, it examines the nature of the unlawful act and the nature and burden of the sanction placed in perspective or applied. Administrative law sanctions and minor offenses are also taken as criminal matter. When classifying administrative sanctions, the criminal nature of the conduct can be judged if the purpose of the declaration the unlawfulness, and the substantive or procedural legal regulation and the applied form of liability have the peculiarities of the criminal legal regulation.

The Constitutional Court in 8/2017. (IV.18.) AB decision interpreted the principle of ne bis in idem regarding the prohibition of twofold assessment of animal welfare fines and criminal liability for cruelty to animals, taking the established

${ }^{21}$ Luca Menci C-524/15. Judgment of 20 March 2018.

22 Judgment of 8 June 1976 in case Engel and Others v Netherlands 5100/71, 5101/71, $5354 / 72,5370 / 72$.

${ }^{23}$ Lukasz Marcin Bonda C-489/10. The judgment of 5 June 2012 applied the Engel criteria in the context of the reduction or exclusion of agricultural support due to the unreal information provided in the application for in the light of criminal proceedings for fraud.

${ }^{24}$ Leopold Henri Van Esbroeck Case C-436/04., Judgment of 9 March 2006, paragraph 2. 
Krisztina Bányai

Thoughts on the principle of ne bis in idem in the light of administrative and criminal sanctions for the legal protection of animals
Journal of Agricultural and

Environmental Law

$31 / 2021$

European case law, accepting the level of legal protection of fundamental rights enshrined in international treaties and in the related case law as a minimum measure. ${ }^{25}$

According to the historical facts, a pet keeper drowned five puppies of his dog in the spring of 2011, for which he was fined to 125,000 HUF for the criminal offense of cruelty to animals, and a few months later the notary fined him to 450,000 HUF on the basis of the facts established in the criminal case. The keeper finally brought an action against the final administrative decision to court, complaining for double punishment. In the lawsuit for the judicial review of the administrative decision on the animal welfare fine the judge suspended the trial and turned to $\mathrm{AB}$.

The $\mathrm{AB}$ stated that the during the application of Section 43 (1) and (4) of the Act, the constitutional requirement of legal certainty and ne bis in idem under Article B (1) and Article XXVIII (6) of the Fundamental Law of Hungary, comes that an animal welfare fine may not be imposed on the same person for the same unlawful act if the criminal liability has been determined. Besides it rejected the judicial initiative to annul the objected legislation.

Article XXVIII (6) of the Fundamental Law says "with the exception of extraordinary cases of legal remedy laid down in an Act, no one shall be prosecuted or convicted for a criminal offence for which he or she has already been finally acquitted or convicted in Hungary or, within the scope specified in an international treaty and a legal act of the European Union, in another State, as provided for by an Act." From the requirement of predictability arising from legal certainty the legislator should regulate the relationship between the various procedures if a conduct is threatened with criminal sanction but it is accompanied by a legal consequence falling within another law field.

Thus, the principle of ne bis in idem does not in itself exclude a person being the subject of several proceedings under the different laws but with a different function for the same unlawful act, which may result in a legal sanction. ${ }^{26}$ The criterion of discrimination will be the nature of the legal sanction, i.e. if there is a sanction for a crime, an administrative sanction with a repressive purpose cannot be applied either. $\mathrm{AB}$ pointed out that from the principle of ne bis in idem comes the constitutional requirement of prohibition of twofold assessment and for the same act in criminal and administrative law sanctions. And to settle the rules arising from the principle of legal certainty is a legislative task.

\section{Sanction Act and the prohibition of twofold assessment}

In order to avoid the double sanctions for the same unlawful act as a result of two parallel or consecutive (administrative and criminal) proceedings with the same content, purpose and function the Act CXXV of 2017 on Administrative sanctions was enacted (hereinafter referred to as: Sanction Act), and after several amendments it finally entered into force on 1st of January 2021.

25 32/2012. (VII.4.) AB decision [41]; 3206/2014. (VII.21.) AB decision [30]; 32/2014. (XI.3.) $\mathrm{AB}$ decision [50].

26 8/2017. (IV.18.) AB decision [49]. 
Krisztina Bányai

Thoughts on the principle of ne bis in idem in the light of administrative and criminal sanctions for the legal protection of animals
Journal of Agricultural and

Environmental Law

$31 / 2021$

Act CLXVIII of 2020 helps its work and tries to establish the coherence of existing legislation at sectoral level by amending certain legislation.

This study, without evaluating Sanction Act, merely seeks to answer the question of whether this legislation is appropriate to avoid multiple proceedings and multiple sanctions of administrative fines for animal protection and criminal liability for cruelty to animals in accordance with the principle of idem. The question is whether this codification would help European standards and the basic system of domestic law to function effectively and to enforce the law.

The scope of Sanction Act extends to the legal consequences (administrative sanction) established by a substantive decision of the administrative authority in case of violations of law (administrative infraction) in administrative authority proceedings based on the Act CL of 2016 on General Public Administration Procedures (hereinafter referred to as: General Public Administration Procedure Act). This introduces the concept of administrative infraction, which is not covered by sectoral legislation, and the term administrative sanction is usually replaced by the word fine (see animal welfare fine in our case), so there is no uniform terminological background, as there are so many specific ones. The regulatory technique of the Sanction Act is specific, discrepany from the act is only permitted if the act allows it itself.

For an administrative infraction the administrative authority shall impose an administrative sanction which may be imposed on a natural person, a legal person or a person with no legal personality who has been found liable for the administrative infraction.

The administrative sanctions for an administrative infraction named in the Sanction Act - thus falling within its scope - are notification, administrative fines, prohibition from carrying out the activity and confiscation, which can be applied even if no liability has been established. The institution of the originally planned administrative bail (a financial disadvantage of a collateral nature, which would have been returned after a year) has been removed from the Act, so its problems should not be examined. However, Sanction Act points to the fact that a law or a government decree issued in its original legislative authority may impose additional administrative sanctions. There are about fifty sectoral legislation, so there are a lot of other instruments. The main objective of Sanction Act is the gradation of administrative sanctions, so the first step is the notitication, which is an expression of disapproval of the authority for preventive purposes, but in some cases its application is excluded. ${ }^{27}$

For enforcing the principle of ne bis in idem, Sanction Act rules that if a court in its final decision has convicted a natural person for an unlawful conduct on the basis of the same facts and imposed a penalty or a measure on him or her; or has acquitted him or her on the grounds that the crime was not committed by the accused;28 no administrative fine or prohibition from an activity shall be imposed. ${ }^{29}$

\footnotetext{
27 Notification is excluded, for example, in cases of Act LIII of 1996 on the Protection of Nature, Section 80 (5a).

28 Act XC of 2017 on criminal proceedings (Criminal Procedure Code, hereinafter referred to as: CPC) Section 566 (1) b).

${ }^{29}$ Sanction Act Section 5/A.
} 
Krisztina Bányai

Thoughts on the principle of ne bis in idem in the light of administrative and criminal sanctions for the legal protection of animals
Journal of Agricultural and

Environmental Law

$31 / 2021$

The reason for the acquittal is therefore relevant, since in the case of other grounds for dismissal, any sanction of the Sanction Act can be applied. Of course, any sanction can also be considered for a fact that has not been assessed in a criminal case (residual facts) or against a natural person whom has not been assessed in a criminal case. If the acquittal is based on the absence of evidence, ${ }^{30}$ the assessment of the evidence can be carried out independently by the administrative authority, as the administrative authority carries out an evidentiary procedure if the available data are not sufficient to make a decision, freely choosing and evaluating the method of proof and the available evidence. ${ }^{31}$ The administrative lawsuit is not bound either by the decision or disciplinary decision of another authority, or by the facts established therein, except for a final adjudicated criminal liability. 32

Sanction Act provides that if the authority imposing an administrative sanction becomes aware that criminal proceedings are in progress for the same unlawful conduct on which its procedure is are based and the application of the administrative sanction depends on the criminal procedure, the administrative authority shall suspend its procedure until the criminal procedure is concluded. ${ }^{33}$ Consequently, administrative sanctions of notification and confiscation can be applied regardless of criminal liability based on Sanction Act as well as other administrative sanctions or measures not covered by Sanction Act, distinguishing criminally and non-criminally threatened administrative infractions. The legislator thus emphasized the primacy of criminal assessment, as it makes the administrative procedure dependent on it. Criminal law threat is ultima ratio in the toolbox of law or it should be. However, it often happens that administrative procedure starts and ends earlier than a criminal procedure does, and the other authority may not even be notified about it. In this respect, however, Sanction Act does not contain any practical rules, it presumes the primacy of the criminal assessment and that the administrative authority also detects this circumstance in time. Administrative proceedings can sometimes produce more results in a shorter period of time than criminal proceedings and may even have a greater deterrent effect. ${ }^{34}$ The ultima ratio nature of criminal prosecution for cruelty to animals is broken by the fact that administrative sanctions sometimes place a greater burden on a person who engages in illegal conduct, and the legal consequences of different weights even raise the question of which law is "cheaper" to prosecute. ${ }^{35}$ The main objective of Sanction Act is to reduce the payment obligations of citizens and undertakings and, in this context, to limit the scope of sanctions that create a real financial disadvantage. ${ }^{36}$ Although this applies to gradual sanctions, it is feared that the reduction of material burdens will be the main principle in multiple proceedings and not necessarily based on the infraction committed.

${ }^{30}$ CPC Section 566 (1) (c).

${ }^{31}$ General Public Administration Procedure Act Section 62 (1) and (4).

32 Act I of 2017 on Administrative Procedure Ordinance Section 85 (6)-(7).

${ }^{33}$ Sanction Act Section 5/B.

34 Beszámoló 2018, 49.

${ }^{35}$ More about this Kajó 2021.

${ }^{36}$ Second paragraph of the general statement of reasons to the Sanction Act. 
Krisztina Bányai

Thoughts on the principle of ne bis in idem in the light of administrative and criminal sanctions for the legal protection of animals
Journal of Agricultural and

Environmental Law

$31 / 2021$

Sanction Act orders to record administrative sanctions in the Register of Administrative Sanctions from the period after its entry into force on 1st of January 2021. The Act does not help the application of law by providing transitional provisions or prohibiting retrospective effect, thus offerss a kind of tabula rasa that is unfair and disproportionate, as these data are taken as a condition of the application of a fine. This public register shall contain data for a period of three years from the date of registration (in theory it is the date of the final administrative decision), which may be accessed by the sanctioning administrative authority in the course of its proceedings. The register is therefore intended to facilitate the gradual sanctioning of administrative infractions and not to eliminate duplication of procedures, because it is not linked to other registers and contains only the decisions of administrative authorities which have been definitively finalized, not those in progress. For this reason, there would still be a need for communication between authorities and even between different areas of the authority. It would be worth considering making this register available to other non-administrative bodies, or even entrusting its management to an organization that is already involved in criminal proceedings.

A good example of communication in various fields is the Prosecutor General Regulation No. 1/2014. (III.31.) on the environmental activities of the Prosecution Service, which emphasizes high importance of special cooperation in the process of environmental prosecution activity, which means the mutual transfer of information, data and documents in compliance with the requirements of continuity and topicality. In practice, this interdisciplinary cooperation means that criminal law prosecutor in case of crimes affecting Chapter XXIII ${ }^{37}$ of Criminal Code informs prosecutor of public interest by sending a copy of the decision rejecting the report, or of the termination decision of investigation, or the expert opinion in the case, as well as the indictment and the court decision in the criminal case. But in the same way, vice versa, the public interest prosecutor also transmits information relevant for the criminal prosecutor, or may even initiate criminal proceedings.

The three-year registration period is adjusted to the limitation period of Sanction Act. ${ }^{38}$ Nevertheless Sanction Act itself pushes the deadline, since it regulates that if criminal proceedings have been initiated for the infringing conduct on which the administrative proceedings are based, an administrative sanction may still be imposed for a period of one more year from the end of the criminal procedure. The regulation on the previous five-year objective limitation period has been removed from the animal protection act.

Administrative fines and prohibition from an activity are priority sanctions. While respecting the principle of ne bis in idem, Sanction Act precludes the application of these administrative sanctions in the case when unlawful conduct is assessed under criminal law, so these depend on the outcome of the criminal proceedings. Sanction Act contains a specific list as a condition for the imposition of an administrative fine, but it is not necessarily able to capture the specifics of the animal welfare administrative

\footnotetext{
${ }^{37}$ Criminal Code Section 241-252. amongst also cruelty to animals is contained in Section 244.

38 The subjective limitation period for an administrative sanction is six months from the detection, while the objective one is up to three years.
} 
Krisztina Bányai

Thoughts on the principle of ne bis in idem in the light of administrative and criminal sanctions for the legal protection of animals
Journal of Agricultural and

Environmental Law

$31 / 2021$

procedure. In case an act may remain unpunished or administrative proceedings may be reduced to sanctioning the rest that criminal proceedings have not assessed. According to András Zs. Varga, ${ }^{39}$ the application of an administrative sanction should not normally depend on other law sanctions, and if the subjective, criminal-based criminal sanction were omitted for any reason, then the administrative law liability would be an advanced rest-liability. Letting the violation of administrative law rules without any sanction would not serve the order..$^{40}$ Sanction Act regarding the double assessment of animal welfare fines and cruelty to animals criminalization, still does not regulate precisely the case when for some reason the administrative procedure precedes criminal procedure. According to Sanction Act the primacy of criminal assessment is the rule and the administrative procedure is adjusted to it. From this phenomenom comes the fear that this may lead to the degradation of administrative liability to a simple mathematical formula, or it easily may mean that administrative procedure is limited to assessing the residual conducts after the criminal procedure. It cannot be the aim of the legislator. Administrative sanctioning is an objective measure, it cannot depend on criminal proceedings, but it has to pay attention to it because of ne bis in idem principle. Due to the requirement of legal certainty, this must be foreseeable and predictable.

In the field of animal protection, in addition to imposing an administrative sanction, the animal welfare authority may take a number of measures, ${ }^{41}$ requiring the keeper to tolerate, or stop an act that is a breach of animal welfare and animal welfare rules, it can impose an obligation, restrict or prohibit the keeper from keeping an animal for a period of 2 up to 8 years depending on the gravity of the infraction. Prohibition may mean a higher financial disadvantage than a suspended imprisonment.

A person who violates or fails to comply with the provisions of law or an authoritative decision on the protection and welfare of animals is obliged to pay an animal welfare fine. The APA in its wording prescribed the imposition of an animal welfare binding, however, the Sanction Act in the case of a criminal threat to an unlawful conduct expressly prohibits it. This would have been worth amending in accordance with the ne bis in idem principle. ${ }^{42}$ Payment of the fine does not exclude other legal consequences. Regarding APA mentions the obligation to training on animal protection or, for example, a ban on keeping an animal or animal species, ${ }^{43}$ but it may even result the confiscation of the animal. The basic amount of the animal protection fine is $15,000 \mathrm{HUF}$, but if the victim of the infraction is a pet animal, the basic amount

\footnotetext{
39 The parallel opinion of András Zs. Varga to 8/2017. (IV.18.) AB to the decision [82]-[87]. 40 8/2017. (IV.18.) AB decision [79]-[89].

41 According to APA Section 42/D an authority, for example, can revoke a permit of functioning, can close an establishment or part of it, can revoke a keeping permit, and can oblige the animal welfare officer to carry out a new training.

42 If the legislator imposes a mandatory imposition of a fine, the legislator may not disregard this legal consequence if it is established that an infraction has been committed. See the 2013.El.II.JGY.1/1/1. II.4.1, 26 of the summary opinion prepared by the law practice-analysing group set up at the Curia on the subject of the examination of "Administrative fines".

43 APA Section 43 (9).
} 
Krisztina Bányai

Thoughts on the principle of ne bis in idem in the light of administrative and criminal sanctions for the legal protection of animals
Journal of Agricultural and

Environmental Law

$31 / 2021$

of the fine is 75,000 HUF. ${ }^{44}$ Government Decree No. 244/1998 (XII.31.) on fines for the protection of animals (hereinafter referred to as: Government Decree) increases the basic amount of the fine by multipliers depending on the circumstances of the infraction..$^{45}$ The highest is the multiplier is ten that must be applied in the case of killing an animal without an acceptable reason or circumstance, or torturing an animal, or in case of abandonment, expulsion, animal fight or inciting an animal. In criminal law, according to the principle of gradation, the minimum of a fine of a perpetrator punished for cruelty to animals is 30.000 HUF when the administrative fine can be a fine of millions. ${ }^{46}$

The perpetrator of the crime is a natural person and not necessarily the keeper of the animal, while an administrative infraction is typically committed by the keeper of the animal, who may even be a legal person against whom the Act CIV of 2001 on criminal measures against legal persons may be applied. Measures (termination of a legal person, restriction of the legal person's activities or a fine) can be applied in the case of an intentional crime, or if the crime was intended or resulted in gaining an advantage for the legal person or was committed using the legal person. ${ }^{47}$

If a keeper who was obliged to participate in animal protection training does not fulfill this obligation voluntarily, the animal protection training or the remaining part of it shall be replaced by an animal protection fine. The question may arise whether the financial conversion of the omission constitutes a pecuniary and repressive sanction or not and if it infringes the principle of ne bis in idem. Because in case of non-fullfillment of animal welfare training the fine would be at least 100,000 HUF, and an animal protection fine of $50,000 \mathrm{HUF}$ corresponds to participation in one day of training. 48 The obligation to report regularly on the keeping and health status of the animals and the use of a person with husbandry experience for the species shall not rise a conflict in case of twofold assessment.

Overall, the criminal law assessment does not affect the aplication of administrative sanctions not defined as primary in Sanction Act, or outside its scope.

\footnotetext{
${ }^{44}$ APA Section 43, and Government Decree Section 2 (1) regulates that the basic amount of the fine is fifteen thousand forints, and from the 7th of January, 2021, in the case of a pet animal, it is seventy-five thousand forints.

45 It depends on the case of several conducts or whether the infraction directly affects the welfare of the animal, or how many vertebrate animals are affected, or whether the act causing the infraction was committed intentionally, or it is a repeated infraction of the same facts within three years. The highest multiplier should be applied for intentional conduct. Government Decree Section 2 (6) f).

46 Of the 78 cases investigated by Kajó, the highest fine was 300,000 HUF, while notaries and district offices imposed fines of millions, tens of millions, for example a fine of 1.6 million HUF was imposed by a notary to an animal keeper because his pet regularly roamed the streets in a self-walking way without having vaccinated against rabies vaccine or a chip, and even caused a traffic accident. Besides a livestock farm was fined to 26 million HUF.

47 Act CIV of 2001. Section 2 (1). Regarding this issue Council Regulation No 2988/95. and Council of Europe Recommendation R (91) 1 should be considered as options for regulating the liability of legal persons.

${ }^{48}$ Government Decree Section 3.
} 
Krisztina Bányai

Thoughts on the principle of ne bis in idem in the light of administrative and criminal sanctions for the legal protection of animals
Journal of Agricultural and

Environmental Law

$31 / 2021$

Many other sectoral administrative sanctions or measures which are not listed in Sanction Act can be applied freely. If an administrative violation occurs, that can result in a priority sanction of the Sanction Act, the result of the criminal proceedings should be taken into account.

\section{Further questions and suggestions}

Several states place the determination of the direction of proceedings in the hands of the prosecutor, ${ }^{49}$ as an actor who also has an insight into the criminal proceedings and has the power to bring civil actions and to initiate a number of official proceedings.

In Hungary, the prosecutor, as a contributor to the administration of justice, shall contribute to the administration of justice by exclusively enforcing the State's demand for punishment as public prosecutor. The prosecution service shall prosecute criminal offenses and take action against other unlawful acts and omissions, as well as contribute to the prevention of unlawful acts..$^{50}$ In its non-criminal competence as a guardian of public interest, exercise further functions and powers laid down in the Fundamental Law or in an Act. ${ }^{51}$ In order to protect public interest, the Prosecution Service shall participate in ensuring that every person observes the law. If legal regulations are violated, the Prosecution Service shall take action to protect legality in the cases and in the manner specified by legislation. ${ }^{52}$ Separate laws on the public interest tasks and powers of the prosecutor's office other than criminal law as a participant in the judiciary are provided for in the law. The prosecutor exercises these powers primarily by instituting court and non-litigation proceedings (right of action) and by initiating official proceedings and bringing legal remedies (action) in order to remedy the offence. ${ }^{53}$ The prosecutor's duties related to environmental and nature protection are performed by the prosecutors appointed for this purpose at county or capital city office of the Prosecutor General, ${ }^{54}$ the prosecutor's duties related to environmental protection and the two-way mechanism of co-operation between the criminal and public interest fields have been regulated separately. ${ }^{55}$ From the point of view of twofold assessment, it may be reasonable to involve the prosecutor more widely in different proceedings and even to have rights over the register of administrative sanctions.

49 In Croatia, since the case of the ECtHR in Maresti v. Croatia (55759/07), the legal environment has changed due to compliance with the ne bis in idem principle, in order to exclude double proceedings, the main initiator of the various proceedings is the prosecutor. Bizjak 2015, 54.

${ }^{50}$ Article 29 (1) of the Fundamental Law of Hungary.

51 Article 29 (2) d) of the Fundamental Law of Hungary.

52 Act CLXIII of 2011on the Prosecution Service, Section 1 (2).

${ }^{53}$ Act CLXIII of 2011 on the Prosecution Service, Section 26 (1).

54 Prosecutor General Directive No. 3/2012. (I.6.) on the public interest tasks of the Prosecution Service, Section 68.

55 Prosecutor General Regulation No. 1/2014. (III.31.) on the environmental activities of the Prosecution Service. 
Krisztina Bányai

Thoughts on the principle of ne bis in idem in the light of administrative and criminal sanctions for the legal protection of animals
Journal of Agricultural and

Environmental Law

$31 / 2021$

In Hungarian penalty system, the most common penalties for cruelty to animals are fines, suspended imprisonment, and also community service work. Some animal rights' activists suggest animal shelters to be the place where the sentence of community service work can be fulfilled. However, this is not so simple, as the willingness of employers cannot be enforced, it requires a voluntary declaration of employment so it is difficult to find a workplace, and the convicting court has no influence on it. In addition, the execution of community service work is often inefficient due to the convicted person's own fault. (does not appear in the probation procedure, does not cooperate in accordance with the law, etc.) Prohibiton to exercise professional activity should also be mentioned that may be imposed upon a person who has committed a criminal offense through the violation of the rules of his/her profession requiring professional qualifications; knowingly, by using his profession, either has the necessary qualification for the profession. ${ }^{56}$ But the introduction of prohibition to animal husbandry as a measure, ${ }^{57}$ or as a rule of conduct besides the penalty, have also been raised.

Cruelty to animals may even involve deferral of prosecution, ${ }^{58}$ as an option for diversion instead of prosecution, which is a means of prosecutorial discretion based on the principle of opportunism. The prosecutor's office may suspend the proceedings if the dismissal can be expected in view of the suspect's future conduct, ${ }^{59}$ and the proceedings shall, as a general rule, impose a sentence of no more than three years' imprisonment, just like cruelty to animals. It is not a decision made in a court proceeding, but it does affect the merits of the case, as after the successful expiry of the period of suspension, the prosecutor terminates the proceedings in this regard. Sanction Act in Section 5/A. mentions only a criminal conviction or acquittal by a court decision as the reason for the exclusion of priority administrative sanction, it does not cover the proceedings terminated by the prosecutor. In international relations, in some states, the closure of criminal proceedings by a prosecutor is seen as a conviction in another state, ${ }^{60}$ it would be worth avoiding double assessment in such a case as well, accepting the dismissal decision of the prosecutor. That would meet the requirements of legal certainty and predictability. The provision providing for the principle of ne bis in idem refers to acquittals and convictions, and the constitutional provision containing the presumption of innocence explicitly and exclusively links the

${ }^{56}$ Criminal Code Section 52.1 (a)(b) and (2).

${ }^{57}$ Beszámoló 2018, 49.

${ }^{58}$ CPC Section 416-420.

${ }^{59}$ Given the nature of the crime, the manner in which it was committed and the identity of the suspect, a favorable change in the suspect's behavior is expected from this parole. CPC Section 416 (2) b).

${ }^{60}$ Joined Cases C-187/01 and C-385/01 Criminal proceedings against Hüseyin Gözütok and Klaus Brügge. In the case of Gözütok the decision of the Dutch public prosecutor's office and in the case of Brügge the decision of the German public prosecutor's office was taken into account by the German and Belgian authorities respectively. 
Krisztina Bányai

Thoughts on the principle of ne bis in idem in the light of administrative and criminal sanctions for the legal protection of animals
Journal of Agricultural and

Environmental Law

$31 / 2021$

final determination of criminal liability to a final court decision, so currently only a court decision is capable of producing a res iudicata effect. ${ }^{61}$

The biggest problem in practice is the temporality problem already indicated; if an administrative procedure has been initiated in an administrative procedure on animal protection case has been completed but in the meantime or afterwards a criminal procedure starts. It is of a theoretical nature, as the administrative clerk can detect and indicate the existence of a criminal offense at the beginning of the administrative proceedure, but this is not always perceptible. So in this case, the administrative decision is legally created as a result of a legal procedure. However, there is no possibility of being this 'taken into account' in any way in criminal proceedings, furthermore the fact of an administrative authority decision may not be either revealed. However, a consistent interpretation of ne bis in idem principle would justify the avoidance of twofold assessment.

The possibility of remedies against the administrative could arise upon request (administrative lawsuit or appeal procedure) or ex officio in accordance with the provisions of the General Public Administration Procedure Act. In the latter case, amending or revoking the decision can fall within the authority's own competence, but the procedure can be initiated by the prosecutor either, ${ }^{62}$ which may also justify the prosecutor's participation in animal protection proceedings. ${ }^{63}$ It seems problematic to establish the subsequent illegality of an otherwise lawful administrative decision at the time of its adoption, if we insist on the primacy of criminal proceedings in case of twofold assessment. Regarding the administrative decision, Tibor Lengyel points to another practical example in his study, ${ }^{64}$ when after the - among others - 252,000 HUF administrative fine, the court during the review of the administrative decision has decreased the fine with the amount of 100,000 HUF fine imposed in the criminal procedure following the basic administrative decision. Thus a criminal sanction, that was applied subsequently in time after the administrative procedure, was taken into account despite of the fact that the prohibition of twofold assessment was emerged in the criminal procedure. It would be entirely appropriate to validate the preliminary administrative procedure as a mitigating circumstance during the imposition of a penalty at criminal courts. In this way, the principle of ne bis in idem could be fully enforced in a guaranteed manner, avoiding the accumulation of administrative and criminal sanctions without degradating the administrative procedure, and thus the constitutional principle of a fair trial could prevail. As Ágnes Czine pointed out, the final decision on liability in animal welfare proceedings should also have an impact on the sanction imposed in criminal proceedings. ${ }^{65}$

\footnotetext{
${ }^{61}$ See Court decision BH2018.301, which expressed that view in relation to the interpretation of Article XXVIII. (2) and (6) of the Fundamental Law.

62 General Public Administration Procedure Act Section 113.

${ }^{63}$ It is important to emphasize that in the absence of scheduled prosecutorial investigations in the previous period, this now requires a starting circumstance (notification, application, etc.).

${ }^{64}$ Lengyel 2020, 65-66.

${ }^{65}$ Dissenting opinion of Ágnes Czine to 8/2017. (IV.18.) AB decision [110].
} 
Krisztina Bányai

Thoughts on the principle of ne bis in idem in the light of administrative and criminal sanctions for the legal protection of animals
Journal of Agricultural and

Environmental Law

$31 / 2021$

The multifaceted issue of prohibiton is also problematic, because the Sanction Act takes prohibition to exercise an activity as a priority sanction and does not allow it to be applied solely depending on the outcome of the criminal proceedings. In the APA, the prohibition can be ordered by the administrative authority in its own competence or on the initiative of the prosecutor, but conceptually it causes some confusion that there is also a prohibition in civil proceedings. The law may entitle the prosecutor to bring an action, in particular in connection with the protection of the environment, nature and arable land. In case of such an action, the public interest in the proceedings shall be presumed. ${ }^{66}$ In case of breaking rules of animal welfare and protection, the prosecutor is entitled to bring an action for prohibition from an activity or compensation for the damage caused by the activity. ${ }^{67}$ The legal consequence of bringing an action is not a sanction in legal terms, but in substance it is, as a civil law obligation initiated on the basis of public interest has a negative effect on the defendant's living conditions as a repressive legal consequence of the infringing conduct. So the question is whether it is consistent with the ne bis in idem prnciple if we examine strictly the Engel criteria. The civil law aspect of prohibition cannot be included in the conceptual framework of prohibition in criminal or administrative law. In the case of an action for damages caused by an activity, it is not in clear to whom the damage is, whether it can be enforced in other legal ways and under what conditions. In the case of a civil law prohibition, it is also questionable how such a prohibition can be enforced in the absence of voluntary performance. Otherwise, this type of civil action is rare in practice, we encounter such actions more often in the activities of animal welfare NGOs in this field, as they have been given a specific role in animal welfare; on the one hand, they have the status of a client in official proceedings brought by them for breaches of animal welfare legislation; on the other hand, such an organization may also bring an action for prohibition of unlawful conduct.

\section{Closing remarks}

Overall, such practical problems can emerge in the application of the Sanction Act indicated above. Thus, a comparison between the administrative procedure for the protection of animals and criminal proceedings for cruelty to animals would justify the existence of a more transparent registration system in terms of the ne bis in idem principle, the precise relationship between the different proceedings, the appropriate communication between the bodies and, possibly, the control of a coordinating body. The further clarification of Sanction Act is needed in order to avoid the accumulation of sanctions, perhaps it may have been better for the Constitutional Court in its relevant decision to annul the provisions of the Act on animal welfare fines with a future effect ${ }^{68}$ in order to ensure full re-regulation, as further practical can occur in this area in the future.

${ }^{66}$ Act CLXIII of 2011 on the Prosecution Service Section 27 (5) (e) and (6).

${ }^{67}$ APA Section 44 (2).

${ }^{68}$ Dissenting opinion of Ágnes Czine to 8/2017. (IV.18.) AB decision [114]. 
Krisztina Bányai

Thoughts on the principle of ne bis in idem in the light of administrative and criminal sanctions for the legal protection
Journal of Agricultural and Environmental Law

$31 / 2021$

\section{Bibliography}

1. Beszámoló (2018) „Az állatkínzás miatt indult büntetőeljárások tapasztalatai és büntetéskiszabási gyakorlata" című kerekasztal-beszélgetésről, Ügyészek Lapja, 2018/1.

2. Bizjak D (2015) The protection of the environment through criminal law in Croatia, PhD Thesis, Central European University, Budapest

3. Commission working document on a Community Action Plan on the Protection and Welfare of Animals 2006-2010 (2006) Strategic basis for the proposed actions, https:// eur-lex.europa.eu/legal-content/HU/TXT/?uri=CELEX:52006DC0014 [30.10.2021]

4. Harmati J \& Kiss Á L (2016) Judgment of the European Court of Human Rights on the prohibition of double assessment Judgment of the joint application of tax fines and criminal convictions, JeMa, 2016/4.

5. Kajó C (2021) A cornerstone from a keystone - the ultimate The elimination of the ultima ratio principle in cruelty to animals offense (with a view to the emerging "forum shopping" due to tendencies in sanctioning, https://www.jogiforum.hu/publikaciok/1138 [30.10.2021]

6. Lengyel $\mathrm{T}$ (2020) The practical barriers regarding the principle of ne bis in idem in terms of criminal and adminsitrative law in Hungary, Belügyi Szemle, 2020/5. 